\title{
The Application of Dipeptidyl Peptidase 4 Inhibitor to the Treatment for Hepatitis C Virus Infection
}

\section{Hidekatsu Yanai ${ }^{*}$ Hisayuki Katsuyama, Hidetaka Hamasaki, Hiroki Adachi, Sumie Moriyama and Akahito Sako}

Department of Internal Medicine, National Center for Global Health and Medicine Kohnodai Hospital, Chiba, Japan

Very recently, Riva A, et al. reported the immunology of viral hepatitis, and showed the role of $\mathrm{C}-\mathrm{X}-\mathrm{C}$ chemokine 10 (CXCL10), a potent chemoattractant for antiviral T-cells and NK-cells, and dipeptidyl peptidase 4 (DPP4), in influencing the clinical outcome of acute hepatitis $\mathrm{C}$ virus (HCV) infection [1].The truncated form of CXCL10 is generated by DPP4, and truncated CXCL10 was associated with failure to achieve spontaneous clearance of acute HCV infection in their study. Increased plasma activity of DPP4 was correlated with the establishment of chronic HCV infection via the generation of a truncated form of CXCL10. In another study, high baseline plasma concentrations of DPP4 were also associated with poor treatment outcome and altered HCV-specific T-cell functionality in a cohort of patients with established chronic $\mathrm{HCV}$ infection treated with Peg-interferon a plus ribavirin [2]. What made a difference in DPP4 activity between patients developing chronicity and patients who spontaneously resolved HCV infection?

HCV infection induces insulin resistance by increasing inflammatory cytokines such as interleukin-6 and tumor necrosis factor- $\alpha$ (Figure1) [3]. DPP4 has a higher release from visceral adipose tissue that is particularly pronounced in obese and insulin-resistant patients [4]. Increased DPP4 activity also induces insulin resistance due to induction of inflammatory cytokines $[5,6]$.Therefore, I am anxious to know whether a difference in insulin resistance and/or obesity exist or not, between patients developing chronicity and patients who spontaneously resolved HCV infection.

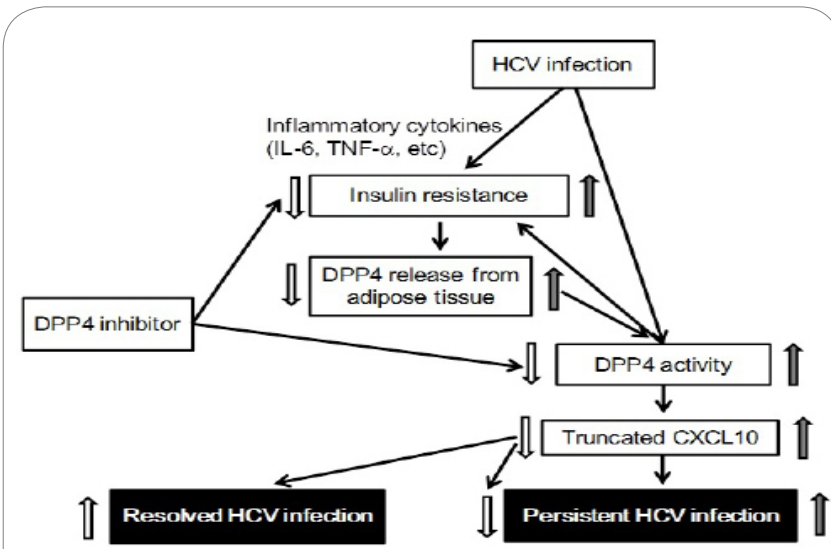

Figure 1: The application of dipeptidyl peptidase- 4 inhibitor to the treatment for hepatitis $\mathrm{C}$ virus infection. Blank arrows indicate the potential effects of dipeptidyl peptidase 4 inhibitor. CXCL, C-X-C chemokine 10; DPP4, dipeptidyl peptidase 4; HCV, hepatitis C virus; IL-6, interleukin-6; TNF- $\alpha$, tumor necrosis factor- $\alpha$.

Insulin resistance and diabetes are major disease modifiers in chronic hepatitis C [7].There is further evidence that insulin resistance provides some sort of survival advantage for $\mathrm{HCV}[7,8]$.It has been shown that patients who have previously failed anti-viral therapy have greater insulin resistance [8]

\section{Publication History:}

Received: June 11, 2014

Accepted: June 23, 2014

Published: June 25, 2014

\section{Keywords:}

Dipeptidyl Peptidase, Hepatitis C Virus, C-X-C chemokine 10

These findings suggest that therapeutic inhibition of DPP4 activity by using DPP4 inhibitors may be a novel strategy to treat HCV infection. DPP4 inhibitors reduce DPP4 activity by itself and also via improvement of insulin resistance, resulting in decease in truncated CXCL10, which induces clearance of HCV infection (Figure 1).

\section{Acknowledgement}

This work was supported by a grant from the National Center for Global Health and Medicine (25-203).

\section{References}

1. Riva A, Laird M, Casrouge A, Ambrozaitis A, Williams R, et al. (2014) Truncated CXCL10 is associated with failure to achieve spontaneous clearance of acute hepatitis $\mathrm{C}$ infection. Hepatology.

2. Söderholm J, Waldenström J, Askarieh G, Pilli M, Bochud PY, et al. (2013) Impact of soluble CD26 on treatment outcome and hepatitis $C$ virus-specific $\mathrm{T}$ cells in chronic hepatitis C virus genotype 1 infection. PLoS One 8: e56991.

3. Sheikh MY, Choi J, Qadri I, Friedman JE, Sanyal AJ (2008) Hepatitis C virus infection: molecular pathways to metabolic syndrome. Hepatology 47 2127-2133.

4. Sell H, Blüher M, Klöting N, Schlich R, Willems M, et al. (2013) Adipose dipeptidyl peptidase-4 and obesity: correlation with insulin resistance and depot-specific release from adipose tissue in vivo and in vitro. Diabetes Care 36: 4083-4090.

5. Pala L, Rotella CM (2013) The role of DPP4 activity in cardiovascula districts: in vivo and in vitro evidence. J Diabetes Res 2013: 590456.

6. Romacho T, Elsen M, Röhrborn D, Eckel J (2014) Adipose tissue and its role in organ crosstalk. Acta Physiol (Oxf) 210: 733-753.

7. El-Zayadi AR, Anis M (2012) Hepatitis C virus induced insulin resistance impairs response to anti viral therapy. World J Gastroenterol 18: 212-224.

8. Poustchi H, Negro F, Hui J, Cua IH, Brandt LR, Kench JG, et al. (2008) Insulin resistance and response to therapy in patients infected with chronic hepatitis $\mathrm{C}$ virus genotypes 2 and 3 . J Hepatol 48: 28-34.

"Corresponding Author: Dr. Hidekatsu Yanai, Department of Internal Medicine National Center for Global Health and Medicine Kohnodai Hospital, 1-7-1 Kohnodai, Chiba, 272-8516, Japan; E-mail: dyanai@hospk.ncgm.go.jp

Citation: Yanai $\mathrm{H}$, Katsuyama $\mathrm{H}$, Hamasaki $\mathrm{H}$, Adachi $\mathrm{H}$, Moriyama $\mathrm{S}$, et al. (2014) The Application of Dipeptidyl Peptidase 4 Inhibitor to the Treatment for Hepatitis C Virus Infection. Int J Diabetes Clin Diagn 1: 101. doi: http://dx.doi. org/10.15344/2394-1499/2014/101

Copyright: @ 2014 Yanai $\mathrm{H}$. This is an open-access article distributed under the terms of the Creative Commons Attribution License, which permits unrestricted use, distribution, and reproduction in any medium, provided the original author and source are credited. 